\title{
Sensitive and Direct Detection of Heterodera filipjevi in Soil and Wheat Roots by Species-Specific SCAR-PCR Assays
}

\begin{abstract}
Huan Peng, Xiaoli Qi, and Deliang Peng, State Key Laboratory for Biology of Plant Diseases and Insect Pests, Institute of Plant Protection, Chinese Academy of Agricultural Sciences, Beijing 100193, China; Haibo Long, Key Laboratory of Pests Comprehensive Governance for Tropical crops, Ministry of Agriculture, P. R. China, Environment and Plant Protection Institute, Chinese Academy of Tropical Agricultural Science, Danzhou 571737, China; Xufeng He, College of Biosafety Science \& Technology, Hunan Agricultural University and Hunan Provincial Key Laboratory for Biology \& Control of Plant Diseases and Insect Pests, Hunan Agricultural University, Changsha 410128, China; and Wenkun Huang and Wenting He, State Key Laboratory for Biology of Plant Diseases and Insect Pests, Institute of Plant Protection, Chinese Academy of Agricultural Sciences, Beijing 100193, China
\end{abstract}

\begin{abstract}
Peng, H., Qi, X., Peng, D., Long, H., He, X., Huang, W., and He, W. 2013. Sensitive and direct detection of Heterodera filipjevi in soil and wheat roots by species-specific SCAR-PCR assays. Plant Dis. 97:1288-1294.

Cereal cyst nematodes are the most important plant-parasitic nematodes on cereal crops in wheat producing areas of the world. Heterodera filipjevi was first reported in China in 2010. In this study, species-specific sequence characterized amplified region-polymerase chain reaction (SCAR-PCR) assays for detection and identification of $H$. filipjevi from infected wheat roots and soil were developed. The species-specific primers were designed according to the randomly amplified polymorphic DNA (RAPD) markers amplified with random primer OPK16. A 646-bp specific fragment of sequence was generated,

which characterized amplified regions in $H$. filipjevi. The detection limitation of the PCR assay was as low as $0.125 \mu \mathrm{l}$ second-stage juvenile (J2) lysate, $3.9 \times 10^{-3} \mu \mathrm{l}$ adult female lysate, and $10^{-3} \mu \mathrm{l}$ cyst lysate. The method was able to detect the various stages (J2, J3, J4, and female) of $H$. filipjevi, and a single of nematode in $0.5 \mathrm{~g}$ of soil. $H$. filipjevi was detected by the method in two of six field samples, and one of those samples contained a mixed population of $H$. filipjevi and $H$. avenae. This study is the first to provide a definitive diagnostic assay for $H$. filipjevi in wheat roots and soil.
\end{abstract}

Cereal cyst nematodes $(\mathrm{CCN})$ consist of a group of 12 closely related species of Heterodera that are considered to be the most economically important plant parasitic nematode of cereal crops in several parts of the world (33). Three species (H. avenae, H. filipjevi, and $H$. latipons) are the most commonly reported species in cultivated cereals (21). H. avenae is a pathogen of cereal crops worldwide and causes significant economic yield losses in many countries. H. filipjevi was first reported in Tadjikistan by Madzhidov (20), and has now been reported in Asia, Europe, and the United States $(12,13,15,28,32,38)$. This species is now considered to be an important pest of cereals worldwide. In Turkey, significant yield losses (average 42\%) in several rain fed winter wheat locations have been reported. In Iran, under microplot field trials, yield losses of $48 \%$ were found on common winter wheat over two wheat seasons $(10,22-24)$. H. filipjevi was recently found in six locations in the Henan Province in China (28).

$H$. filipjevi is closely related to $H$. avenae and has minor morphological characteristics that differentiate it from $H$. avenae $(11,34,38)$. The traditional identification of $H$. filipjevi based on morphology and morphometric characteristics is time-consuming. The use of isozyme analysis and molecular methods for the identification of $H$. filipjevi has increased, as these methods are fast and can be more accurate than the traditional method. However, isozyme analysis is only performed with white females, not single second-stage juveniles (J2), males, or cysts $(2,6)$. Polymerase chain reaction (PCR) restriction fragment length polymorphism (RFLP) based on the internal transcribed spacer (ITS) region of the ribosomal repeat unit assay has been used extensively for diagnosis and characterization of $H$. filipjevi $(4,8,19,33-36,39)$. Restriction

Corresponding author: Deliang Peng, E-mail: dlpeng@ippcaas.cn

Accepted for publication 9 April 2013.

http://dx.doi.org/10.1094/PDIS-02-13-0132-RE

(C) 2013 The American Phytopathological Society enzyme PstI clearly differentiated $H$. filipjevi from other members of the $H$. avenae group (34). Two types of RFLP patterns generated by $C f o I$ have been obtained from different populations of $H$. filipjevi (33). Yan and Smiley (39) used PCR-ITS-RFLP with up to six restriction endonucleases (TaqI, HinfI, PstI, HaeIII, RsaI, and $A l u \mathrm{I}$ ) to differentiate $H$. filipjevi from $H$. avenae. Although the ITS regions are very useful for species identification, polymorphism occurs between rDNA repeats within one species, resulting in different RFLP patterns which can overlap with the RFLP pattern for another species (37).

DNA fingerprinting by random amplified polymorphic DNA (RAPD) is another powerful PCR-based technique that has been applied successfully to the identification and estimation of molecular genetic diversity in various nematode species, including Heterodera spp. (18,31). The method has been employed to distinguish between $H$. cruciferae and $H$. schachtii (7). By comparing the patterns obtained from RAPD, species-specific fragments can be identified and used to design species-specific primers. These primers are used to generate the sequence characterized amplified region (SCAR) (27). SCAR-PCR analysis is a rapid and reliable technique and has been used successfully to distinguish the species Globodera rostochiensis, G. pallida (9), and H. glycines (26). SCAR markers have also been developed to distinguish between $H$. avenae and other cyst forming nematodes (30).

The aim of this work was to develop a species-specific PCR assay to facilitate the detection and identification of $H$. filipjevi from wheat roots and soil. This study demonstrated that this is a potentially valuable method for early detection and monitoring of $H$. filipjevi infection in the field.

\section{Materials and Methods}

Nematode populations. Nine populations of $H$. filipjevi and nine other nematode species were used in this study (Table 1). The cysts were stored at $4^{\circ} \mathrm{C}$ for 6 weeks, and then placed in water at $16^{\circ} \mathrm{C}$. Hatched $\mathrm{J} 2 \mathrm{~s}$ were collected using sieves daily and stored at $4^{\circ} \mathrm{C}$. Ten core subsamples of 10 to $20 \mathrm{~cm}$ deep were taken by spade from infected wheat fields of 0.5 to 1 ha. Combined, those subsam- 
ples made one composite sample to represent the wheat roots. A total of 15 root samples were collected from wheat-growing areas of Beijing, Henan, and Shandong Provinces.

DNA extraction. Nematode genomic DNA extraction was as described in Ou et al. (26). Wheat tissue samples were triturated in liquid nitrogen, and DNA was extracted by the phenol chloroform method (29). Total DNA was extracted from artificially inoculated soil and field soil using the Power Soil DNA Isolation Kit (MoBio, Carlsbad, CA) according to the manufacturer's recommendations. All of the DNA templates were quantified using the NanoDrop ND-1000 Spectrophotometer (Thermo Fisher Scientific Inc., Wilmington, DE).

RAPD-PCR analysis and SCAR primer design. Ten random primers were used for amplifying and analyzing specific fragments of $H$. filipjevi (Table 2). Amplification reactions were carried out in total volumes of $25 \mu$ l containing $2.5 \mu \mathrm{l} 10 \times$ PCR buffer, $2.0 \mu \mathrm{l} 2.5$ $\mathrm{mM}$ dNTPs, $1 \mathrm{U}$ rTaq DNA polymerase (TaKaRa, Dalian, China), $50 \mathrm{ng}$ primer, and $1 \mu \mathrm{l}$ nematode template DNA. For RAPD amplifications, the thermocycler was programmed for $4 \mathrm{~min}$ at $94^{\circ} \mathrm{C}$; followed by 10 cycles of $30 \mathrm{~s}$ at $94^{\circ} \mathrm{C}, 30 \mathrm{~s}$ at $35^{\circ} \mathrm{C}$, and $1 \mathrm{~min}$ at $72^{\circ} \mathrm{C}$, and 30 cycles of $30 \mathrm{~s}$ at $94^{\circ} \mathrm{C}, 1 \mathrm{~min}$ at $37^{\circ} \mathrm{C}$, and $1 \mathrm{~min}$ at $72^{\circ} \mathrm{C}$; with a final extension at $72^{\circ} \mathrm{C}$ for $10 \mathrm{~min}$. Control reactions without template DNA were included to avoid misinterpretations of the RAPD patterns due to artifacts. The PCR products were separated by electrophoresis on a $1 \%$ agarose gel, stained with ethidium bromide, visualized and photographed under UV-light
(Bio-Rad DX, USA). All reactions were repeated three times and always included negative (no template DNA) controls. A RAPD fragment of $H$. filipjevi obtained with OPK16 was extracted from the gel, purified, and cloned into the PMD18-T simple vector (TaKaRa). Sequencing of the inserts was performed by TaKaRa Biotechnology. Specific SCAR primers pairs HfF1 and HfR1 (Table 2) were designed using Primer 5.0, and the initial sequences are the RAPD primer OPK16 sequence.

Species-specific amplification. Nine populations of $H$. filipjevi and seven populations of other cyst nematodes were selected to test specificity (Table 1). SCAR amplification reactions were performed in 50- $\mu \mathrm{l}$ reaction volumes containing $5 \mu \mathrm{l} 10 \times$ PCR buffer, $10 \mathrm{mM}$ dNTPs, $2 \mathrm{U}$ rTaq DNA polymerase (TaKaRa), $1 \mu \mathrm{l}$ template DNA, $20 \mathrm{pM}$ each of forward and reverse primers (HfF1 and HfR1) plus sterile distilled water to a total volume of $50 \mu \mathrm{l}$. The amplification was carried out in an Eppendorf Mastercycler Gradient thermocycler, with the following cycling profile: $4 \mathrm{~min}$ at $94^{\circ} \mathrm{C}$; followed by 35 cycles of $30 \mathrm{~s}$ at $94^{\circ} \mathrm{C}, 30 \mathrm{~s}$ at $56^{\circ} \mathrm{C}$, and $1 \mathrm{~min}$ at $72^{\circ} \mathrm{C}$; with a final extension at $72^{\circ} \mathrm{C}$ for $10 \mathrm{~min}$. The PCR product's purification, cloning, and sequencing was as described above.

Sensitivity of specific primers. For the sensitivity test, the genomic DNA of single J2s, adult females, and cysts of $H$. filipjevi were serially diluted in twofold, fourfold, and 10-fold increments with sterile distilled water, respectively. Different dilutions of genomic DNA were separately detected by specific primers and were repeated three times.

Table 1. Cyst and other nematode populations studied and polymerase chain reaction (PCR) amplified products obtained during testing of the specific sequence characterized amplified region (SCAR) marker combinations

\begin{tabular}{|c|c|c|c|c|}
\hline Code & Species name & Population origin & Plant host & SCAR \\
\hline Hf1 & H. filipjevi & Xuchang County, Xuchang, Henan, China & Triticum aestivum & + \\
\hline Hf2 & H. filipjevi & Banpopu County, Xuchang, Henan, China & Triticum aestivum & + \\
\hline Hf3 & H. filipjevi & Fudaoxiang, Tangyin, Henan, China & Triticum aestivum & + \\
\hline Hf4 & H. filipjevi & Fudaoxiang, Tangyin, Henan, China & Triticum aestivum & + \\
\hline Hf5 & H. filipjevi & Yuguosi county, Weihui, Henan, China & Triticum aestivum & + \\
\hline Hf6 & H. filipjevi & Yuguosi county, Weihui, Henan, China & Triticum aestivum & + \\
\hline Hf7 & H. filipjevi & Tabuk Population Saudi Arabia & Triticum sp. & + \\
\hline Hf8 & H. filipjevi & Khuzestan Province Iran & Triticum sp. & + \\
\hline Hf9 & H. filipjevi & Markaz Province Iran & Triticum sp. & + \\
\hline Ha1 & H. avenae & Yiyang, Taian, Shandong, China & Triticum aestivum & - \\
\hline $\mathrm{Ha} 2$ & H. avenae & Linxia, Gansu, China & Triticum aestivum & - \\
\hline $\mathrm{Hg} 1$ & H. glycines & Qingyundian, Daxing, Beijing, China & Glycine $\max$ & - \\
\hline $\mathrm{Hg} 2$ & H. glycines & Tongwei, Gansu, China & Glycine $\max$ & - \\
\hline Hgo1 & H. goettingiana & Hubei, China & Glycine $\max$ & - \\
\hline He1 & H. elachista & Changsha, Hunan, China & Oryza sativa & - \\
\hline Hl1 & H. latipons & Saudi Arabia & Triticum sp. & - \\
\hline Dd1 & Ditylenchus destructor & Tongshan, Jiangsu, China & Solanum tuberosum & - \\
\hline Rs1 & Radopholus similis & Haikou, Hainan, China & Pandanus utilis & - \\
\hline
\end{tabular}

a + Indicates the presence of amplified fragment; - indicates the absence of amplified fragment.

Table 2. Codes and sequences of primers

\begin{tabular}{|c|c|c|c|}
\hline Primer name & Sequences $\left(5^{\prime} \rightarrow 3^{\prime}\right)$ & Usage & Reference \\
\hline OPA02 & TGCCGAGCTG & RAPD primer & (26) \\
\hline OPA03 & AGTCAGCCAC & & \\
\hline OPA06 & GGACCCTGAC & & \\
\hline OPA09 & GGGTAACGCC & & \\
\hline OPA13 & CAGCACCCAC & & \\
\hline OPA18 & AGGTGACCGT & & \\
\hline OPB15 & GGAGGGTGTT & & \\
\hline OPC06 & AAGACCCCTC & & \\
\hline OPD13 & GGGGTGACGA & & \\
\hline OPG06 & GTGCCTAACC & & \\
\hline OPG08 & TCACGTCCAC & & \\
\hline OPK16 & GAGCGTCGAA & & \\
\hline HfF1 & CAGGACGAAACTCATTCAACCAA & H. filipjevi-specific primers & This study \\
\hline HfR1 & AGGGCGAACAGGAGAAGATTAGA & & \\
\hline $\mathrm{HaF} 1$ & TGACGAGAACATATGATGGGGATGAT & H. avenae-specific primers & (30) \\
\hline HaR1 & GAGGGGGTGGGAATGAAATGGAT & & \\
\hline TW81 & GTTTCCGTAGGTGAACCTGC & ITS universal primers & (14) \\
\hline AB28 & ATATGCTTAAGTTCAGCGGGT & & \\
\hline
\end{tabular}


Direct detection of $\boldsymbol{H}$. filipjevi from artificially inoculated wheat roots and soil. Wheat, Triticum aestivum ' Wenmai 19', was cultured in a glasshouse in $300 \mathrm{~cm}^{3}$ volume pots containing autoclaved soil. Four seeds were planted into each pot, and 1,000 $\mathrm{J} 2 \mathrm{~s}$ of $H$. filipjevi were inoculated into the soil near the wheat roots of 6-day-old seedlings. Pots were incubated at $16^{\circ} \mathrm{C}$ for the first week and then $22^{\circ} \mathrm{C}$ for the remaining growth period, as described by Long et al. $(16,17)$. Wheat roots were treated with sterile distilled water as a negative control. Wheat roots were collected at $5,10,30$, and 40 days after inoculation (DAI); at each time period a portion of the wheat roots were stained by acid fuchsin (5) and observed under the microscope, and the other part was used to extract DNA as described above. Every sample was repeated five times. The PCRs were the same as those employed for the SCAR-

Table 3. Detection of Heterodera filipjevi from naturally infected wheat roots and soil using sequence characterized amplified region (SCAR) marker

\begin{tabular}{|c|c|c|c|c|c|c|c|}
\hline \multirow[b]{2}{*}{$\begin{array}{l}\text { Field } \\
\text { samples }\end{array}$} & \multirow[b]{2}{*}{ Location } & \multicolumn{3}{|c|}{ Roots (5-cm segments) } & \multicolumn{3}{|c|}{ Soil } \\
\hline & & $\begin{array}{c}\text { Nematode } \\
\text { density }^{a}\end{array}$ & $\begin{array}{c}\text { SCAR } \\
\text { (detections/trial) }\end{array}$ & ITS-RFLPb & $\begin{array}{l}\text { Nematode } \\
\text { density }^{c}\end{array}$ & $\begin{array}{c}\text { SCAR } \\
\text { (detections/trial) }\end{array}$ & ITS-RFLPb $^{b}$ \\
\hline DXBJ & Qingyudian, Daxing, Beijing & $7 \pm 3$ & $0 / 10$ & - & 4 & $0 / 5$ & - \\
\hline TYHN & Fudaoxiang, Tangyin, Henan & $7 \pm 4$ & $7 / 10$ & + & 7 & $3 / 5$ & + \\
\hline $\mathrm{XCHN}$ & Banpopu, Xuchang, Henan & $11 \pm 2$ & $9 / 10$ & + & 5 & $3 / 5$ & + \\
\hline $\mathrm{ZZHN}$ & Zhengzhou, Henan & $9 \pm 2$ & $0 / 10$ & - & 3 & $0 / 5$ & - \\
\hline FCSD & Feicheng, Shandong & $12 \pm 5$ & $0 / 10$ & - & 7 & $0 / 5$ & - \\
\hline ZBSD & Linzi, Zibo, Shandong & $4 \pm 2$ & $0 / 10$ & - & 6 & $0 / 5$ & - \\
\hline
\end{tabular}

${ }^{\text {a }}$ Numbers of Heterodera spp. were counted after being stained by acid fuchsin in 5-cm-long root segments.

${ }^{\mathrm{b}}$ Sample was infested by a mixed population of $H$. filipjevi and $H$. avenae as determined by using internal transcribed spacer restriction fragment length polymorphism (ITS-RFLP) with TaqI. + Indicates the presence of the $H$. filipjevi-specific fragment; - indicates the absence of the $H$. filipjevi-specific fragment.

${ }^{\mathrm{c}}$ Numbers of Heterodera spp. were counted after Baermann funnel extraction for $24 \mathrm{~h}$ from $200 \mathrm{~g}$ of soil.

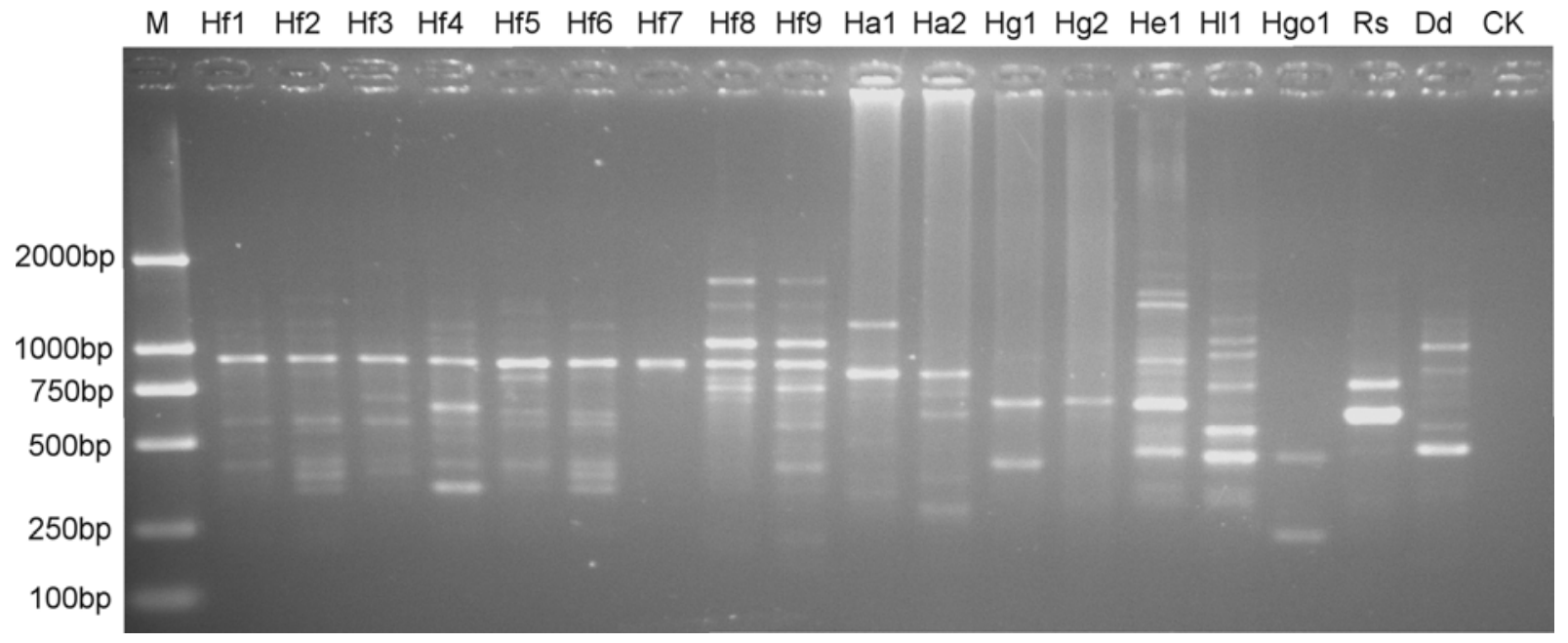

Fig. 1. Random amplified polymorphic DNA (RAPD) patterns of 18 populations of nematodes using primer OPK16. Hf, Heterodera filipjevi; Ha, $H$. avenae; Hg, $H$. glycines; He, H. elachista; HI, H. latipons; Hgo, H. goettingiana; Rs, Radopholus similis; Dd, Ditylenchus destructor, M, DL 2,000 DNA marker; CK, negative control.

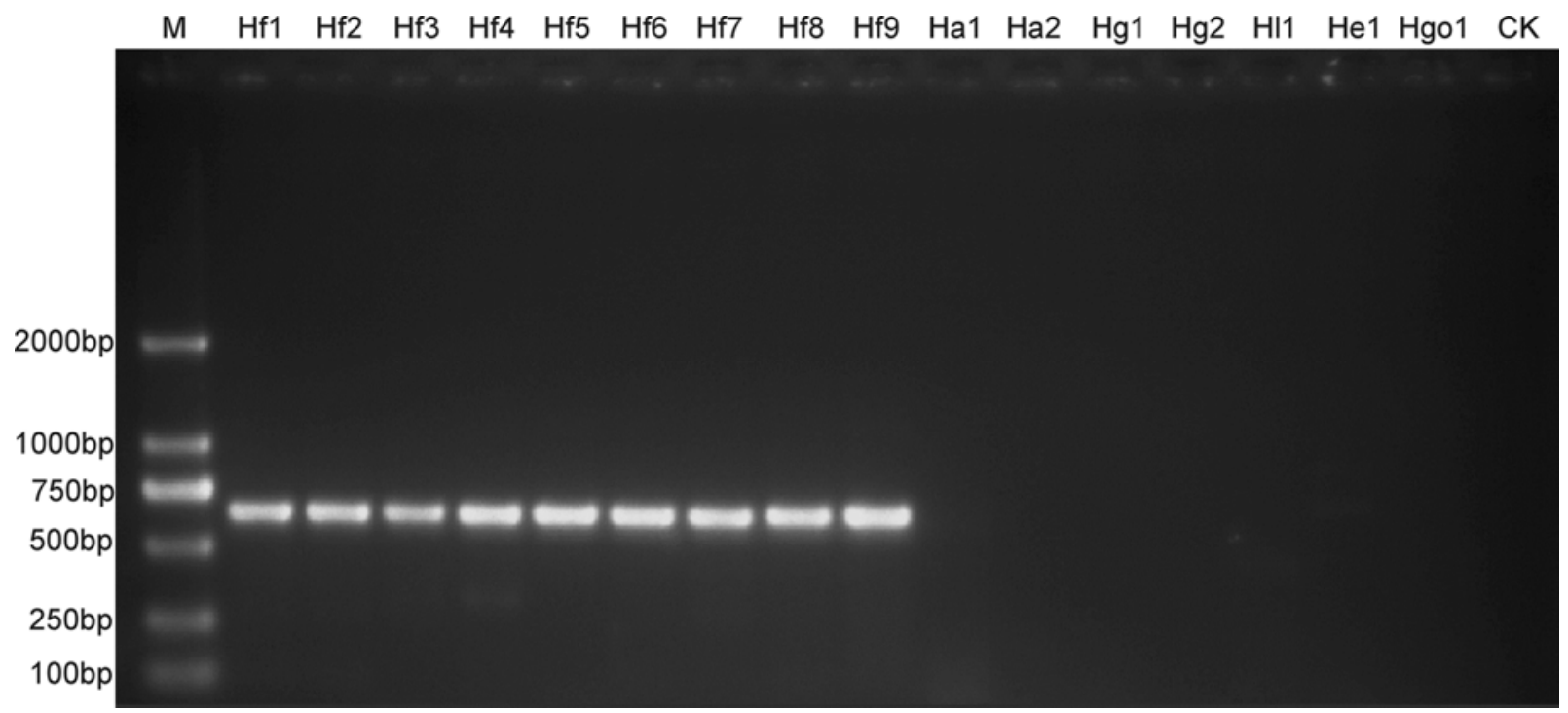

Fig. 2. Amplification products obtained by sequence characterized amplified region (SCAR) primers for Heterodera filipjevi and other related nematode populations. Hf, H. filipjevi; Ha, H. avenae; Hg, H. glycines; HI, H. latipons; He, H. elachista; Hgo, H. goettingiana; M, DNA marker DL 2,000; CK, negative control. 
PCR above, except that 40 cycles and plus $1 \mu \mathrm{l}$ of BSA were used. Meanwhile, in order to ensure that the DNA templates were working, the ITS fragments of $H$. filipjevi were amplified from all samples with the primer set of TW81 and AB28 (Table 2). In addition, $1,2,3,4$, or $5 \mathrm{~J} 2$ of $H$. filipjevi were picked and placed into 2-ml tubes with $0.5 \mathrm{~g}$ of autoclaved soil. Autoclaved soil alone served as the negative control. The genomic extraction and PCR detection were as described above.

Direct detection of $\boldsymbol{H}$. filipjevi from naturally infested wheat roots and soil. Wheat roots and soil samples collected from six fields infested with cereal cyst nematodes in Henan, Shandong, and Beijing Provinces were used to test for $H$. filipjevi using SCARPCR assay and ITS-RFLP with TaqI (Table 3). Wheat roots were carefully cleaned with distilled water. Ten wheat roots $(5 \mathrm{~cm}$ each) were randomly selected from each sample, and 0.5 -g soil samples (repeated five times) were taken from each completely mixed sample. Genomic DNA extraction and PCR detection were as described above. Results were confirmed by both ITS-RFLP assay as described by Yan and Smiley (39) and $H$. avenae-specific primers HaF1 and HaR1 (Table 2) as described by Qi et al. (30). As a comparison, numbers of Heterodera sp. were counted from roots (10 roots, $5 \mathrm{~cm}$ each root) and $200 \mathrm{~g}$ of soil using acid fuchsin staining and after extraction using the Baermann funnel, respectively.

\section{Results}

RAPD-PCR analysis. In the RAPD-PCR with the 10 primers, four primers (OPK16, OPA02, OPA03, and OPA09) produced clear bands from template DNA of all $H$. filipjevi populations. Other primers produced either complex RAPD patterns or none. Because OPK16 produced RAPD patterns with bands that clearly distinguished $H$. filipjevi from other cyst forming nematodes, OPK16 was subsequently tested on the populations listed in Table 1 (Fig. 1)

Design of specific primers and species-specific amplification. The species-specific fragment of $H$. filipjevi obtained with OPK16 was sequenced and submitted to GenBank (KC529338). The specific SCAR primer pairs (HfF1 and HfR1) were designed according to the result of SCAR sequences (Table 2). The species-specific 646-bp fragment was amplified from nine $H$. filipjevi populations. No amplification could be obtained from other species of cyst nematodes, including $H$. avenae, $H$. glycines, $H$. goettingiana, $H$. elachista, and $H$. latipons (Fig. 2).

Sensitivity detection. Three developmental stages of $H$. filipjevi (J2s, adult females, and cysts) were used to determine the sensitivity of species-specific primers. As shown in Figure 3, the minimum detection concentration required for the SCAR assay is $0.125 \mu \mathrm{J} 2$ lysate with 40 PCR cycles, $3.9 \times 10^{-3} \mu$ l adult female lysate, and $10^{-3} \mu$ l cyst lysate with 35 PCR cycles. No amplification was observed in no-template and lower template concentrations.

Direct detection of $\boldsymbol{H}$. filipjevi from artificially inoculated wheat roots and soils. For the inoculated wheat roots, 646-bp specific bands were found at 5, 10, 30, and 40 DAI (Fig. 4A). Additionally, 1,054-bp ITS fragments were produced from all of the inoculated wheat roots; BLAST results showed that these ITS sequences were the same as those of $H$. filipjevi. Microscopic observations showed that $H$. filipjevi developed as parasitic J2, thirdstage (J3), fourth-stage (J4) juveniles, and adult females at 5, 10, 30, and 40 DAI, respectively (Fig. 4B). Thus, these results demonstrated that this is a useful detection method for these developmental stages of $H$. filipjevi. Additionally, the PCR-SCAR assay can accurately detect one juvenile in a 0.5 -g soil sample (Fig. 4C). No bands were generated from noninoculated wheat roots and autoclaved soil using the PCR-SCAR assay.

Direct detection of $\boldsymbol{H}$. filipjevi from naturally infested wheat roots and soil. Positive results were obtained using SCAR and ITS-RFLP in TYHN and XCHN, with detection rates of $70 \%$ (7/10) and 90\% (9/10), respectively. However, the 1,010-bp fragment was also produced from TYHN samples using $H$. avenaespecific primers, and a 370-bp H. filipjevi-specific band and a 400bp $H$. avenae-specific band were obtained from TYHN samples by ITS-RFLP with TaqI, suggesting that the TYHN sample contained mixed species of cereal cyst nematodes. No amplifications were observed in the remaining four samples (DXBJ, ZZHN, FCSD, and ZBSD) by PCR-SCAR assay; however, 1,010-bp fragments were generated from these samples using $H$. avenae-specific primers, and 400-bp $H$. avenae-specific marker was also observed in these samples using ITS-RFLP with TaqI (Table 3), indicating that these samples contained only $H$. avenae.

\section{Discussion}

The cereal cyst nematode, $H$. filipjevi, is an important worldwide pest of cereals and was recently found in North China (28). The nematode is closely related to $H$. avenae, and these two species have very small differences in both morphology and ITS sequence features $(1,4,8,33,34,36,39)$. The major morphological differences between $H$. filipjevi and $H$. avenae are the underbridge and bullae in the vulval cone $(33,34,39)$. Morphological identification is unreliable even when done by skilled researchers, and these morphological differences are not suitable for use by technicians with limited professional knowledge.

Molecular techniques can help with species identification, but those used until now have limitations. PCR-RFLP sometimes needs combinations of expensive restriction enzymes. Due to polymorphisms and because of limitations of the technique itself, it remains difficult to distinguish among Heterodera species; moreover, these techniques are time-consuming and laborious. Therefore,
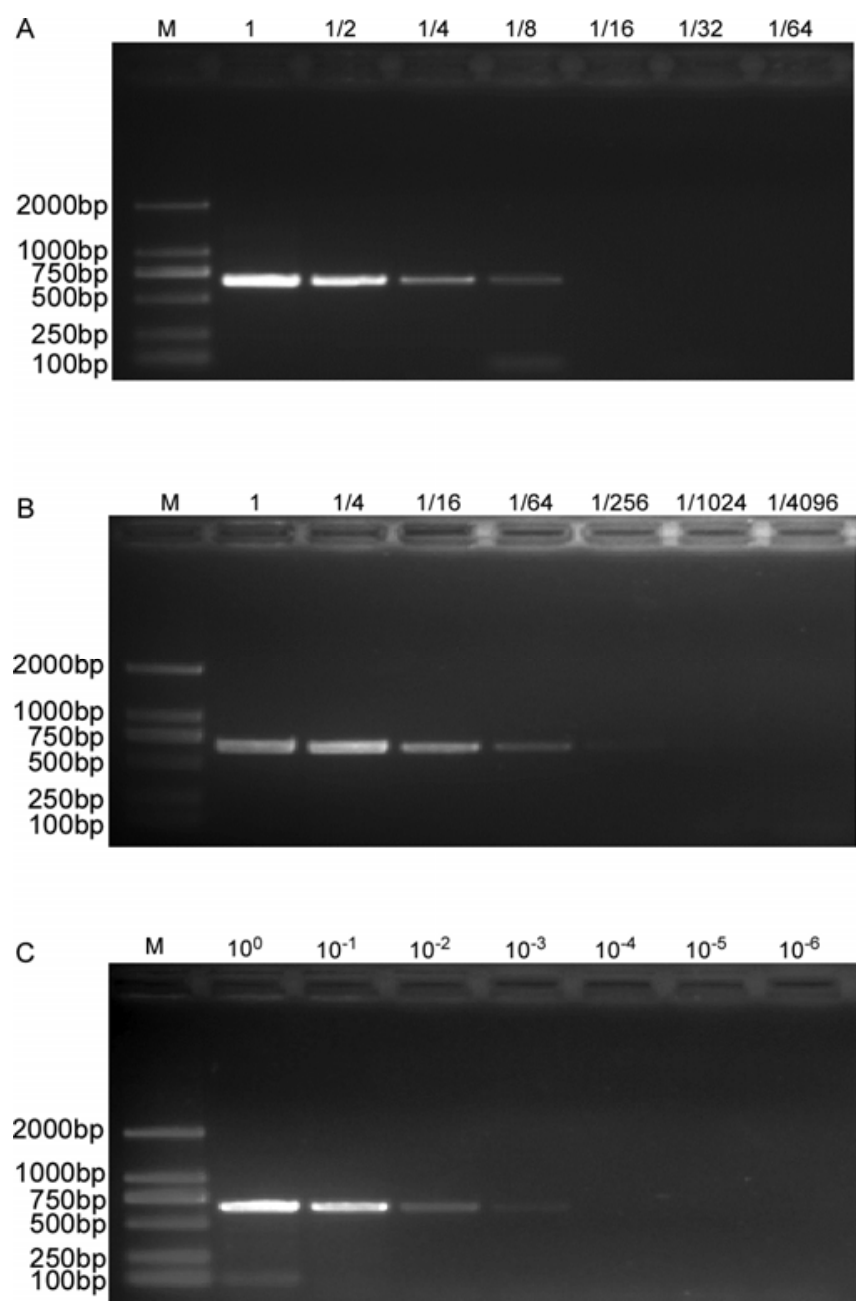

Fig. 3. Sensitivity assessment of the sequence characterized amplified region (SCAR) marker for the detection of Heterodera filipjevi: A, performed with serial dilution of DNA from a single second-stage juvenile of $H$. filipjevi $(1,1 / 2,1 / 4,1 / 8$, $1 / 16,1 / 32,1 / 64$ per reaction); $B$, performed with serial dilution of DNA from a single female of $H$. filipjevi $(1,1 / 4,1 / 16,1 / 64,1 / 256,1 / 1024$, and $1 / 4096$ per reaction); C, performed with serial dilution of DNA from a single cyst of $H$. filipjevi $\left(1,10^{-1}\right.$, $10^{-2}, 10^{-3}, 10^{-4}, 10^{-5}$, and $10^{-6}$ per reaction). M, DL 2,000 DNA size marker. 
we developed a diagnostic assay using SCAR markers as an alternative to current detection assays. A pair of primers ( $\mathrm{HfF} 1$ and HfR1) were designed from the species-specific RAPD fragment and successfully used to detect $H$. filipjevi in plant tissue and soil.
The SCAR assay for $H$. filipjevi has excellent specificity and sensitivity, and is rapid. Blast results showed that the sequence of the selected OPK16 RAPD fragment had no similarity with any known sequences in the NT and NR databases; the RAPD sequence was specific to $H$. filipjevi. Our results showed that $H$. filip-

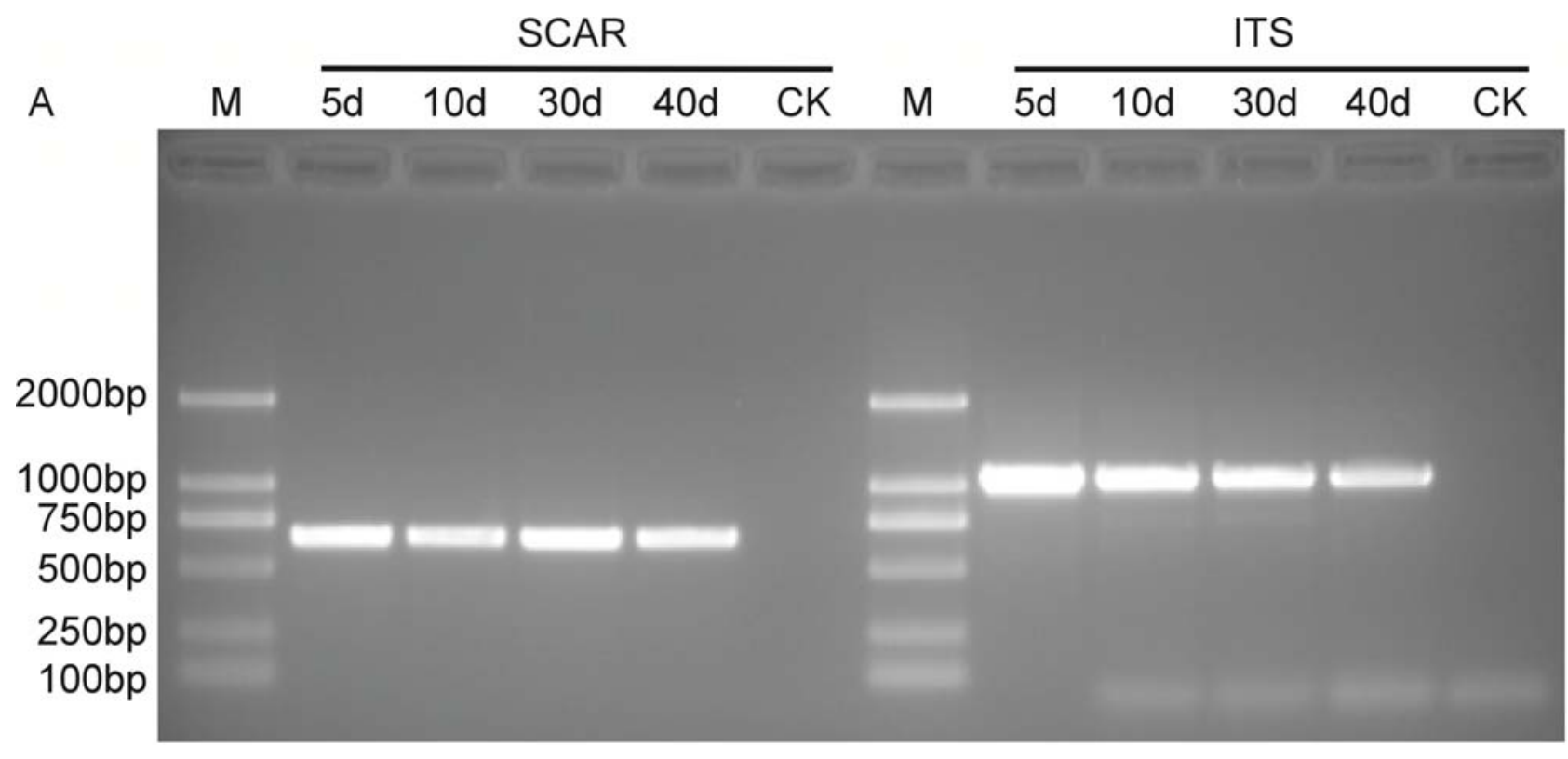

B
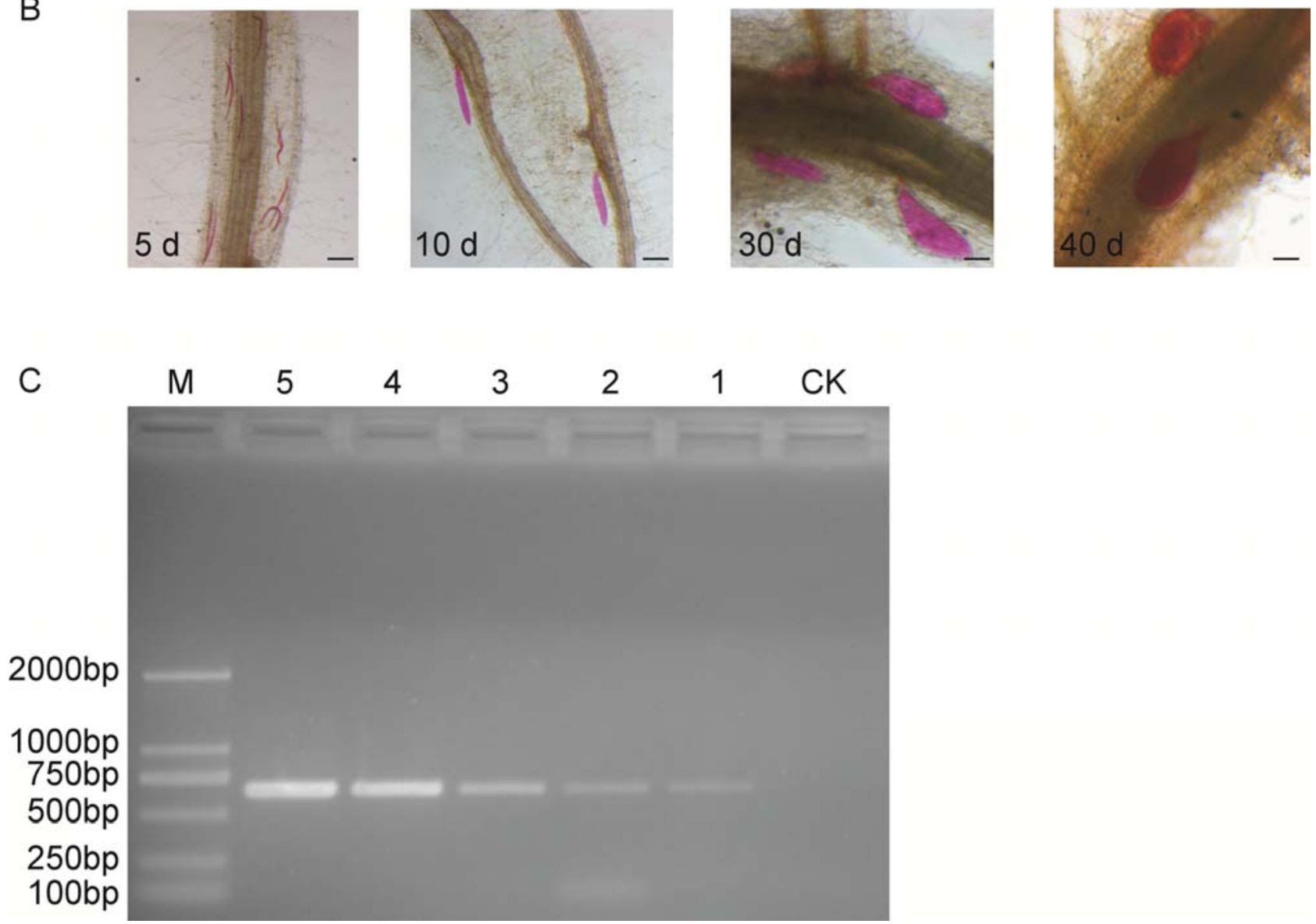

Fig. 4. Amplification products from inoculated wheat roots with sequence characterized amplified region (SCAR) marker and internal transcribed spacer (ITS) primer: A, performed at four different times (days) after inoculation with Heterodera filipjevi (5, 10, 30, and 40 days) using SCAR marker and ITS primer; noninoculated roots as the control; B, H. filipjevi developing in wheat roots at 5, 10, 30, and $40 \mathrm{DAl}$ (stained); C, detection of $H$. filipjevi from 5, 4, 3, 2, and $1 \mathrm{~J} 2 \mathrm{~s}$ in $0.5 \mathrm{~g}$ of soil; autoclaved soil as the control (CK). M, DL 2,000 DNA size marker. Bar $=20 \mu \mathrm{m}$. 
jevi differed from $H$. avenae, $H$. latipons, $H$. glycines, $H$. elachista, and $H$. goettingiana using the SCAR marker, which was based on the specific RAPD sequence. Additionally, the SCAR assay was sensitive enough to detect at least 1/160th of a juvenile, 1/5120th of a female and $5 \times 10^{-4}$ of a cyst, demonstrating the very high sensitivity of the assay. This sensitivity compares well with previous studies. Qi et al. (30) reported that the sensitivity of specific $H$. avenae SCAR marker was $1 / 80$ th of a juvenile and $5 \times 10^{-3}$ of a cyst. The SCAR method has many advantages compared with the ITS-RFLP method. Subbotin et al. (33) showed that digestion with $R s a \mathrm{I}$ and $A l u \mathrm{I}$ allowed separation of $H$. filipjevi from the European $H$. avenae populations (type A) and the three French populations (type $\mathrm{A}+\mathrm{B}$ ) but did not separate $H$. filipjevi from the Indian population (type B). Yan and Smiley (39) reported that $H$. filipjevi and $H$. avenae can be distinguished by PCR-RFLP using six restriction enzymes; however, PCR-RFLP produced many bands which are difficult to visualize. The RFLP assay also sometimes needs combinations of expensive restriction enzymes and is timeconsuming. In contrast, we can obtain clear results within $3 \mathrm{~h}$ by the SCAR method.

In order to determine which life stages of $H$. filipjevi could be effectively detected in the root by SCAR-PCR, PCRs were performed using template DNA from individual wheat roots at 5, 10, 30 , and $40 \mathrm{DAI}$, which spans the entire period of morphological development of these nematodes (parasitic J2s, J3s, J4s, and adult females). The results indicated that $H$. filipjevi could be detected at all stages of development in wheat roots. Positive PCR amplifications were performed in all samples tested, including each of the five repetitions. Thus, this study showed the assay can serve as a detection tool to diagnose early nematode infection in the plant root at stages where there is absolutely no visual indication of infection.

The SCAR-PCR assay can detect one juvenile in $0.5 \mathrm{~g}$ of soil, equating to 2,000 juveniles $/ \mathrm{kg}$ of soil. Lower numbers of nematodes were not examined, and no band was generated from the noninoculated soil sample. This sensitivity compares well with findings reported by other researchers. Ophel-Keller et al. (25) detected fewer than one egg of $H$. avenae per gram of soil by realtime PCR. Yan et al. (40) were also able to detect single juveniles of Pratylenchus neglectus and P. thornei per gram of soil, and Atkins et al. (3) detected 30 juveniles of Nacobbus per gram of soil. More importantly, the detection sensitivity obtained in the present study was lower than the economic threshold level for $H$. filipjevi. Hajihasani et al. (10) showed that a density of five $H$. filipjevi eggs or juveniles per gram of soil or fewer caused a loss of about $10 \%$ of wheat yield. Consequently, this method will not only be of use to detect and monitor $H$. filipjevi, but also will be useful for assessing disease risk and recommending management strategies. In the present study, the approach was successfully used for detection of $H$. filipjevi in naturally infested field samples, including wheat roots and soil, indicating the high potential of this method. H. filipjevi was detected in two of six samples, and the rates of positive results were 70 and $90 \%$ from wheat roots in two locations (Tangyin and Xuchang) in Henan Province by the SCAR assay. Although we counted the number of nematodes in a part of the roots equal to that used for the SCAR assay, we cannot be certain that the roots from which DNA was extracted had the same numbers of nematodes. For the sample from Xuchang, where $H$. filipjevi in China was first reported, there was no amplification by SCAR and ITS primer in one of 10 roots, indicated that not all roots in an infected sample may contain nematodes. In samples from Tangyin, $H$. filipjevi was not detected in three out of 10 roots, but $H$. avenae was detected using ITS-RFLP and $H$. avenae-specific primers; thus, the samples from Tangyin were infected by a mixed population of $H$. filipjevi and $H$. avenae. This is the first report of the existence of cereal cyst nematodes, including $H$. filipjevi and $H$. avenae, near Tangyin in Henan Province. In comparison with plant samples, the number of positive results was less in both of the soil samples (60\%). The samples were collected in May 2012, when cereal cyst nematodes would have hatched and invaded the plants and developed to J4 and female stages; at that time, only a few juveniles and adult males would remain in the soil. Additionally, in this study, DNA was extracted from $0.5 \mathrm{~g}$ of soil using a commercial kit, and although the samples were thoroughly mixed, the nematodes may not have been selected because the size of the samples was too small. Thus, in order to avoid the risk of nondetection, multiple repeat examinations for field samples will be necessary.

In the present study, we report for the first time a $H$. filipjevispecific PCR-SCAR assay and its use to detect the nematode directly from plant tissue and soil. The assay is a sensitive, practical, and rapid technique for the detection of $H$. filipjevi and has the potential to be used for early detection and monitoring of $H$. filipjevi infestation in the field.

\section{Acknowledgments}

This study was supported by the National Key Basic Research Program of China (973 Program, 2013CB127502), the Special Fund for Agro-scientific Research in the Public Interest (No. 200903040), and by National Natural Science Foundation of China (No. 31201493). The first and second authors contributed equally to this work. Professors Roland Perry (Rothamsted Research, UK) and Richard W. Smiley (Oregon State University, USA) are thanked for their scientific advice and useful revision of this manuscript. We also thank Dr. Julie M. Nicol for providing $H$. filipjevi and $H$. latipons.

\section{Literature Cited}

1. Abidou, H., Valette, S., Gauthier, J. P., Rivoal, R., El-Ahmed, A., and Yahyaoui, A. 2005. Molecular polymorphism and morphometrics of species of the Heterodera avenae group in Syria and Turkey. J. Nematol. 37:146154.

2. Andres, M. F., Romero, M. D., Montes, M. J., and Delibes, A. 2001. Genetic relationships and isozyme variability in the Heterodera avenae complex determined by isoelectrofocusing. Plant Pathol. 50:270-279.

3. Atkins, S. D., Manzanilla-Lopez, R. H., Franco, J., Peteira, B., and Kerry, B. R. 2005. A molecular diagnostic method for detecting Nacobbus in soil and in potato tubers. Nematology 7:193-202.

4. Bekal, S. F., Gauthier, J. F., and Rivoal, R. 1997. Genetic diversity among a complex of cereal cyst nematodes inferred from RFLP analysis of the ribosomal internal transcribed spacer region. Genome 40:479-486.

5. Bird, A. F. 1983. Changes in the dimensions of the oesophageal glands in root-knot nematodes during the onset of parasitism. Int. J. Parasitol. 13:343348.

6. Bishnoi, S. P., Singh, S., Mehta, S., and Bajaj, H. K. 2004. Isozyme patterns of Heterodera avenae and $H$. filipjevi populations of India. Indian J. Nematol. 34:33-36.

7. Caswell-Chen, E. P., Williamson, V. M., and Wu, F. F. 1992. Random amplified polymorphic DNA analysis of Heterodera cruciferae and $H$. schachtii populations. J. Nematol. 24:343-351.

8. Fu, B., Yuan, H. X., Zhang, Y., Hou, X. S., Nian, G. L., Zhang, P., Xing, X. P., Sun, B. J., Riley, I. T., and Li, H. L. 2011. Molecular characterisation of cereal cyst nematodes in winter wheat on the Huang-Huai floodplain of China using RFLP and rDNA-ITS sequence analyses. Australas. Plant Pathol. 40:277-285.

9. Fullaondo, A., Barrena, E., Viribay, M., Barrena, I., Salazar, A., and Ritter, E. 1999. Identification of potato cyst nematode species Globodera rostochiensis and G. pallida by PCR using specific primer combinations. Nematology 1:157-163.

10. Hajihasani, A., Tanha Maafi, Z., Nicol, J. M., and Rezaee, S. 2010. Effect of the cereal cyst nematode, Heterodera filipjevi, on wheat in microplot trials. Nematology 12:357-363.

11. Handoo, Z. A. 2002. A key and compendium to species of the Heterodera avenae group (Nematoda: Heteroderidae). J. Nematol. 34:250-262.

12. Holgado, R., Andersson, S., and Magnusson, C. 2006. Management of cereal cyst nematodes, Heterodera spp., in Norway. Commun. Agric. Appl. Biol. Sci. 71:639-645.

13. Holgado, R., Andersson, S., Rowe, J. A., and Magnusson, C. 2004. First record of Heterodera filipjevi in Norway. Nematol. Mediterr. 32:205-211.

14. Huang, W. K., Ye, W. X., Jiang, H. Y., Long, H. B., Peng, H., Wang, G. F., and Peng, D. L. 2012. Genetic variation analysis of Heterodera avenae Wollenweber (Nematoda: Heteroderidae) using ISSR marker and ITSrDNA sequence. Asian J. Nematol. 1:1-12.

15. Li, H. L., Yuan, H. X., Sun, J. W., Fu, B., Nian, G. L., Hou, X. S., Xing, X. P., and Sun, B. J. 2010. First record of the cereal cyst nematode Heterodera filipjevi in China. Plant Dis. 94:1505.

16. Long, H., Peng, H., Huang, W., Wang, G., Gao, B., Moens, M., and Peng, D. 2012. Identification and molecular characterization of a new $\beta-1,4-$ endoglucanase gene (Ha-eng-1a) in the cereal cyst nematode Heterodera avenae. Eur. J. Plant Pathol. 134:391-400.

17. Long, H. B., Peng, D. L., Huang, W. K., Peng, H., and Wang, G. F. 2013. Molecular characterization and functional analysis of two new $\beta-1,4$-endo- 
glucanase genes (Ha-eng-2, Ha-eng-3) from the cereal cyst nematode Heterodera avenae. Plant Pathol. 62:953-960.

18. Lopez-Brana, I., Romero, M. D., and Delibes, A. 1996. Analysis of Heterodera avenae populations by the random amplified polymorphic DNA technique. Genome 39:118-122.

19. Madani, M., Vovlas, N., Castillo, P., Subbotin, S. A., and Moens, M. 2004. Molecular characterization of cyst nematode species (Heterodera spp.) from the mediterranean basin using RFLPs and sequences of ITS-rDNA. J. Phytopathol. 152:229-234.

20. Madzhidov, A. R. 1981. Bidera filipjevi n. sp. (Heteroderina: Tylenchida) in Tadzhikistan. Izv. Akad. Nauk Tadzh. SSR Otd. Biol. Nauk 2:40-44.

21. McDonald, A. H., and Nicol, J. M. 2005. Nematode parasites of cereals. Pages131-191 in: Plant Parasitic Nematodes in Subtropical and Tropical Agriculture. M. Luc, R. A. Sikora, and J. Bridge, eds. CAB International,Wallingford, UK.

22. Nicol, J. M., Bolat, N., Sahin, E., Tülek, A., Yıldırım, A. F., Yorgancılar, A., Kaplan, A., and Braun, H. J. 2006. The cereal cyst nematode is causing economic damage on rain-fed wheat production systems of Turkey. (Abstr.) Phytopathology 96:S169.

23. Nicol, J. M., Elekçioğlu, I. H., Bolat, N., and Rivoal, R. 2007. The global importance of the cereal cyst nematode (Heterodera spp.) on wheat and international approaches to its control. Commun. Agric. Appl. Biol. Sci. 72:677-686.

24. Nicol, J. M., Turner, S. J., Coyne, D. L., Nijs, L. d., Hockland, S., and Maafi, Z. T. 2011. Current nematode threats to world agriculture. Pages 2143 in: Genomics and Molecular Genetics of Plant-Nematode Interactions. J. Jones, G. Gheysen, and C. Fenoll, eds. Springer, Netherlands.

25. Ophel-Keller, K., McKay, A., Hartley, D., Herdina, and Curran, J. 2008. Development of a routine DNA-based testing service for soilborne diseases in Australia. Australas. Plant Pathol. 37:243-253.

26. Ou, S. Q., Peng, D. L., Liu, X. M., Li, Y., and Moens, M. 2008. Identification of Heterodera glycines using PCR with sequence characterised amplified region (SCAR) primers. Nematology 10:397-403.

27. Paran, I., and Michelmore, R. W. 1993. Development of reliable PCR-based markers linked to downy mildew resistance genes in lettuce. Theor. Appl. Genet. 85:985-993.

28. Peng, D. L., Ye, W. X., Peng, H., and Gu, X. C. 2010. First report of the cyst nematode (Heterodera filipjevi) on wheat in Henan Province, China. Plant
Dis. 94:1262.

29. Peng, H., Peng, D. L., Hu, X. Q., He, X. F., Wang, Q., Huang, W. K., and He, W. T. 2012. Loop-mediated isothermal amplification for rapid and precise detection of the burrowing nematode, Radopholus similis, directly from diseased plant tissues. Nematology 14:977-986.

30. Qi, X. L., Peng, D. L., Peng, H., Long, H. B., Huang, W. K., and He, W. T. 2012. Rapid molecular diagnosis based on SCAR marker system for cereal cyst nematode. Sci. Agric. Sinica 45:4388-4395.

31. Silva, A. T. d., Penna, J. C. V., Goulart, L. R., Santos, M. A. D., and Arantes, N. E. 2000. Genetic variability among and within races of Heterodera glycines Ichinohe assessed by RAPD markers. Genet. Mol. Biol 23:223-229.

32. Smiley, R. W., Yan, G. P., and Handoo, Z. A. 2008. First record of the cyst nematode Heterodera filipjevi on wheat in Oregon. Plant Dis. 92:1136.

33. Subbotin, S. A., Sturhan, D., Rumpenhopst, H. J., and Moens, M. 2003. Molecular and morphological characterisation of the Heterodera avenae complex species (Tylenchida: Heteroderidae). Nematology 5:515-538.

34. Subbotin, S. A., Waeyenberge, L., Molokanova, I. A., and Moens, M. 1999. Identification of species from the Heterodera avenae group by morphomometrics and ribosomal DNA RFLPs. Nematology 1:195-207.

35. Tanha Maafi, Z., Subbotin, S. A., and Moens, M. 2003. Molecular identification of cyst-forming nematodes (Heteroderidae) from Iran and a phylogeny based on ITS-rDNA sequences. Nematology 5:99-111.

36. Umarao, G. T., and Vangapandu, S. 2008. Molecular characterization of Indian populations of Heterodera filipjevi in tomato using PCR-RFLP of rDNA. Int. J. Nematol. 18:118-122.

37. Wouts, W. M., Rumpenhorst, H. J., and Sturhan, D. 2001. Heterodera betae sp. $n$., the yellow beet cyst nematode (Nematoda: Heteroderidae). Russian J. Nematol. 9:33-42.

38. Yan, G. P., and Smiley, R. W. 2008. First detection of the cereal cyst nematode Heterodera filipjevi in North America. (Abstr.) Phytopathology 98:S176.

39. Yan, G. P., and Smiley, R. W. 2010. Distinguishing Heterodera filipjevi and $H$. avenae using polymerase chain reaction-restriction fragment length polymorphism and cyst morphology. Phytopathology 100:216-224.

40. Yan, G. P., Smiley, R. W., and Okubara, P. A. 2012. Detection and quantification of Pratylenchus thornei in DNA extracted from soil using real-time PCR. Phytopathology 102:14-22. 